[Agr. Biol. Chem., Vol. 31, No. 10, p. 1237 1241, 1967]

\title{
Isolation of Alkaline Proteinase from Aspergillus sojae in Homogeneous Form*
}

\author{
By Kazuya Hayashi, Danji Fukushima and Koya Mogi \\ Central Research Institute of Kikkoman Shoyu Co., Ltd. \\ Noda-shi, Chiba-ken \\ Received May 1, 1967
}

\begin{abstract}
The alkaline proteinase of Aspergillus sojae was isolated in gram quantities as a homogeneous form. The purification procedures were, (1) batchwise-treatment with ion exchange resin Duolite CS 101, (2) fractional precipitation with ammonium sulfate, (3) precipitation with acetone, (4) column chromatography on DEAE-cellulose, and (5) gel filtration with Sephadex G-100. The recovery of the activity was about $12 \%$. The purified enzyme preparation was found to be homogeneous by several criteria such as ultracentrifugation, paper and moving-boundary electrophoreses, etc. Any kinds of carbohydrate and phosphorus were not detected in this preparation, suggesting that this enzyme is a simple protein.
\end{abstract}

Aspergillus sojae," which is widely used in the microbial industry in Japan as is Aspergillus oryzae, is known to produce large amount of an extracelluler alkaline proteinase. The purification of this enzyme has been tried by several investigators, ${ }^{2 \sim 41}$ but it has not been isolated so far in the homogeneous form. As for an alkaline proteinase from Aspergillus oryzae, its purification has been tried by many workers. $^{5 \sim 101}$ However, any preparation which

* Presented at the Annual Meeting of the Agricultural Chemical Society of Japan, Tokyo, March 31, 1967.

1) K. Sakaguchi and K. Yamada, J. Agr. Chem. Soc. Japan, 20, 65 (1945).

2) T. Mizunuma and N. Iguchi, Bull. Agr. Chem. Soc. Japan, 22, 35 (1958).

3) K. Yamamoto and K. Hayashi, Symp. Enz. Chem., (Tokyo) 18, 21 (1961).

4) K. Oda, This Journal, 27, 767 (1963).

5) W.G. Crewther and F.G. Lennox, Nature, 165, 680 (1950).

6) S. Akabori, B. Hagihara, T. Ikenaka and N. Sakota, Symp. Enz. Chem. (Tokyo), 8, 49 (1953).

7) U. Miura, J. Agr. Chem. Soc. Japan, 32, 486 (1958).

8) B. Hagihara, Enzyme, 4, 193 (1960).

9) R. Bergkvist, Acta Chem. Scand., 17, 1521 (1963).

10) Y. Nunokawa and Y. Iyama, $J$. Brewing Soc. Japan, 58, 57 (1963). was homogeneous both electrophoretically and ultracentrifugically was not obtained. Recently, the alkaline proteinase from Aspergillus oryzae has been isolated in homogeneous form ${ }^{11}$ and studied on some physical and chemical properties of the molecule. ${ }^{12)}$ However, little is known about the genetic relationship between the proteinases from different species of yellow aspergilli.

In the previous paper, ${ }^{131}$ authors reported the outline of purification procedure and molecular characteristics on this enzyme. The present paper describes the purification procedure of Aspergillus sojae alkaline proteinase starting from wheat bran culture and some evidence as a simple protein in detail.

\section{EXPERIMENTAL}

Assay of proteinase activity. The proteinase activity was measured by a modification of the Anson's

11) A. R. Subramanian and G. Kalnitsky, Biochem., 3, 1861 (1964).

12) A.R. Subramanian and G. Kalnitsky, ibid., 3, 1868 (1964).

13) K. Hayashi, D. Fukushima and K. Mogi, This Journal, 31, 642 (1967). 
method.14) To $1 \mathrm{ml} 2 \%$ milk casein solution containing $0.2 \mathrm{M}$ phosphate buffer at $\mathrm{pH} 7.5$ was added $1 \mathrm{ml}$ of enzyme solution at $30^{\circ} \mathrm{C}$. After incubation for ten minutes, the reaction was stopped by an addition of $4 \mathrm{ml}$ of $5 \%$ trichloroacetic acid, followed by filtrating. One $\mathrm{ml}$ of the resulted filtrate was mixed with $5 \mathrm{ml}$ of $0.4 \mathrm{M} \mathrm{Na} \mathrm{CO}_{3}$ and then $1 \mathrm{ml}$ of phenol reagent15) was added to it. The optical density of the color developed was measured at $660 \mathrm{~m} \mu$. One proteinase unit (PU) was defined as $1 \mu \mathrm{g}$ of tyrosine liberated in the reaction mixture per one minute under the conditions described above.

Determination of protein. Protein content was assayed spectrophotometrically assuming that $E_{1 \mathrm{~cm}}^{1 \%}$ at $280 \mathrm{~m} \mu$ of protein was 8.98 , which was estimated by the dry weight measurement of the purified enzyme preparation.

Analysis of carbohydrates and phosphorus. Sugar content was determined by phenol- $\mathrm{H}_{2} \mathrm{SO}_{4}$ method ${ }^{16}$ ) and orcin- $\mathrm{H}_{2} \mathrm{SO}_{4}$ method.17) Pentose was determined by orcin- $\mathrm{HCl}-\mathrm{FeCl}_{3}$ method.18) Hexosamine and uronic acid were analysed by Elson-Morgan's method 19) and naphthoresorcinol method,20) respectively. AllenNakamura's method ${ }^{21}$ ) was applied for the determination of phosphorus.

Ultracentrifugation. Sedimentation analysis was carried out at $10^{\circ} \mathrm{C}$ with a Hitachi model UCA-1 analytical ultracentrifuge.

Moving-boundary electrophoresis. The procedure was carried out with a Hitachi-Tiselius electrophoresis apparatus model HTD- 1 at $0^{\circ} \mathrm{C}$.

Paper-electrophoresis. Paper-electrophoresis was performed on the Toyo filter paper No. $51,2 \times 40 \mathrm{~cm}$, for sixteen hours at $500 \mathrm{~V}$ with currents of 4 to $6 \mathrm{~mA}$. The zone of protein was detected by staining with Ponceau 3R.

14) M. L. Anson, J. Gen. Phisiol., 22, 79 (1938). 15) O. Folin and V. Ciocalteu, J. Biol. Chem., 73, 627 (1927).

16) M. Dubois, K. A. Gilles, J. K. Hamilton, P. A. Rebers and F. Smith, Anal. Chem., 28, 350 (1956).

17) M. Sфrensen and G. Hangaad, Biochem. Z., 260, 247 (1933).

18) W. Mejbau, Z. Physiol. Chem, 258, 117 (1939).

19) L. A. Elson and W. T. J. Morgan, Biochem. J., 27, 1824 (1933).

20) F. C. Koch and M. E. Hanke, "Practical Methods in Biochemistry," (1948) p. 17.

21) M. Nakamura, J. Agr. Chem. Soc. Japan, 24, 1 (1950).

\section{RESULTS}

\section{1) Isolation of the Enzyme}

This enzyme was first purified partially by the modification of the method reported by Mizumuma et al., ${ }^{21}$ followed by the application of chromatographical methods into the homogeneous state.

Preparation of crude enzyme extract. Six kilograms of wheat bran culture of Aspergillus sojae strain X816 was extracted with 201 of water overnight at $4^{\circ} \mathrm{C}$. Sixteen liters of the clear solution was obtained by filtration using hyflosupercel.

Batchwise-treatment with Duolite CS 101. Duolite CS 101 resin $(1.6 \mathrm{~kg})$ treated with $0.05 \mathrm{M}$ acetate buffer of $\mathrm{pH} 4.8$ was added to the crude enzyme solution adjusted to $\mathrm{pH} 4.8$ and stirred frequently. After four hours the proteinase-adsorbed resin was separated by the filtration, washed with 201 of the same buffer described above, and then added into 4.51 of $0.2 \mathrm{M}$ phosphate buffer of $\mathrm{pH} 7.6$. The resin suspension was adjusted to $\mathrm{pH} 5.3$ with $10 \mathrm{~N}$ $\mathrm{NaOH}$, stirred for two hours and filtrated. The volume of filtrate was 41 .

Fractionation with ammonium sulfate. To the resin-treated extract was added, with constant stirring, solid ammonium sulphate to give 55\% saturation. The resulting precipitate was removed by filtration. To the filtrate was added further solid ammonium sulphate to give $80 \%$ saturation. The resulting precipitate was separated by filtration, dissolved in $400 \mathrm{ml}$ of cold water and dialized over night against water at $4^{\circ} \mathrm{C}$.

Fractionation with acetone. Acetone was added to the dialized enzyme solution gradually at $-10^{\circ} \mathrm{C}$ to the final concentration of $60 \%$. The resulting precipitate was collected by the centrifugation at $-5^{\circ} \mathrm{C}$, dissolved in $150 \mathrm{ml}$ of cold water, and dialized for two days at $4^{\circ} \mathrm{C}$.

Column chromatography on DEAE-cellulose. DEAE-cellulose (Brown) was equilibrated with $0.02 \mathrm{M}$ phosphate buffer of $\mathrm{pH} 7.5$. The treated cellulose suspension was poured into a column $(3 \times 90 \mathrm{~cm})$ and allowed to settle 

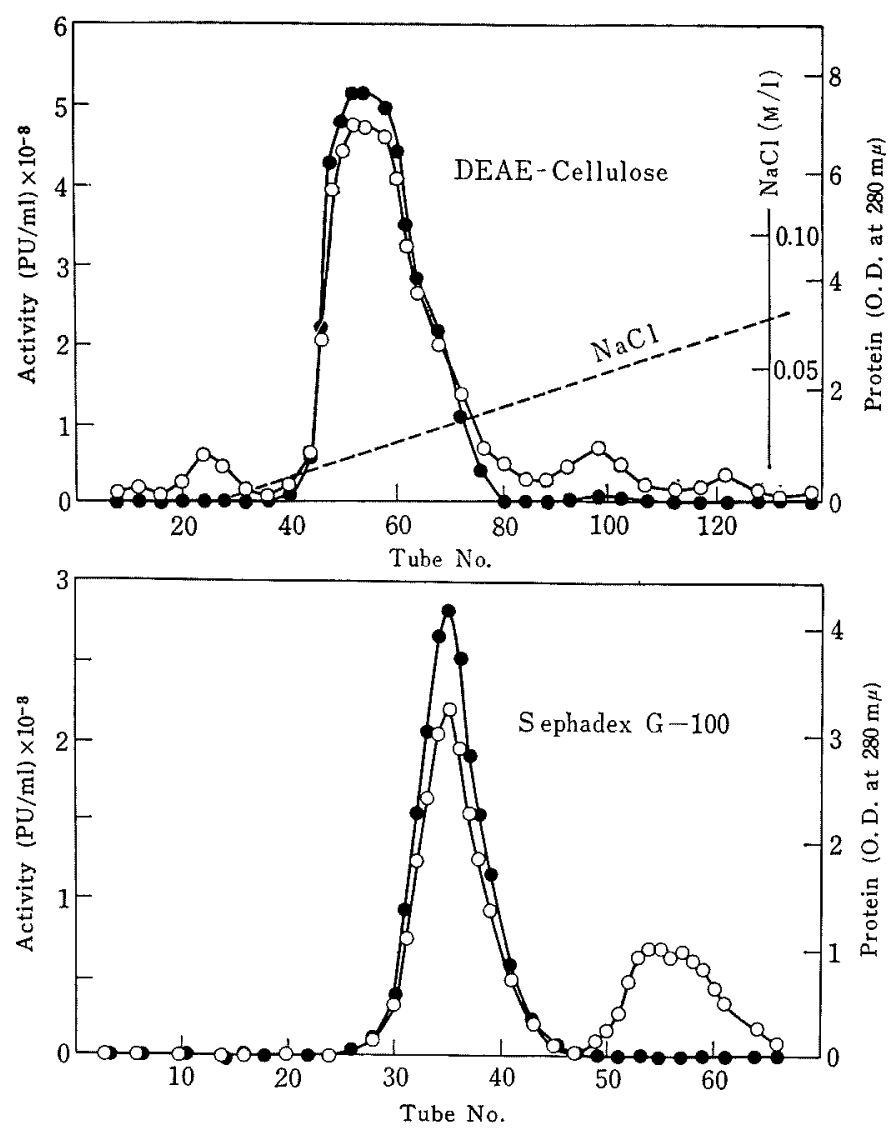

FIG. 1. Elution Patterns of Alkaline Proteinase from Aspergillus sojae on DEAE-cellulose (top) and Sephadex G-100 (bottom). For experimental conditions see the text.

$\bigcirc \longrightarrow$ Protein

- Proteolytic activity

under gravity. The dialized enzyme solution described above was put onto this column. Gradient elution was performed introducing 0.3 s sodium chloride solution containing the same buffer, through a 11 mixing chamber containing the same buffer. The rate of flow was adjusted to $100 \sim 120 \mathrm{ml} / \mathrm{hr}$, and $10 / \mathrm{ml}$ fractions were collected. A typical elution pattern is shown in Fig. 1. The combined contents of tubes $40 \sim 72$ from the DEAE-cellulose column were collected, desalted by dialysis, and then lyophilized.

Gel filtration on Sephadex G-100. Five hundred mg portion of lyophilized preparation was applied to a Sephadex G-100 (Pharmacia, Uppsala, Sweden) column $(2 \times 90 \mathrm{~cm})$ equilibrated with $0.02 \mathrm{M}$ ammonium acetate buffer of $\mathrm{pH}$ 6.0. Elution was performed with the same buffer and $10 \mathrm{ml}$ fractions were collected. Fig. 1 showed a typical elution pattern. The combined contents of tubes $26 \sim 42$ were collected and lyophilized.

The purification accomplished by these operations was summarized in Table I. The specific activity of the alkaline proteinase from Aspergillus sojae was shown to be $816 \mathrm{PU} / \mathrm{mg}$, which was about $20 \%$ higher than that of the crystalline preparation by the previous method 
Table I. Purification of Alkaline Proteinase of Aspergillus sojae

$\begin{array}{lcccc}\text { Procedure } & \begin{array}{c}\text { Vol. } \\ (\mathrm{ml})\end{array} & \begin{array}{c}\text { Total Activity } \\ \left(\mathrm{PU} \times 10^{-4}\right)\end{array} & \begin{array}{c}\text { Specific Activity } \\ (\mathrm{PU} / \mathrm{mg} \text { Protein })\end{array} & \begin{array}{c}\text { Yield } \\ (\%)\end{array} \\ & 16000 & 712 & 8.52 & 100 \\ \text { solution } & 4000 & 395 & 122 & 55.4 \\ \text { atment with Doulite CS 101 } & 500 & 292 & 309 & 44.1 \\ \text { with ammonium sulfate } & 100 & 170 & 417 & 23.9 \\ \text { pitation } & 640 & 134 & 645 & 18.8 \\ \text { se chromatography } & 300 & 86 & 816 & 12.1\end{array}$

Crude enzyme solution

Batchwise treatment with Doulite CS 101

Fractionation with ammonium sulfate

Acetone precipitation

86

816

12.1

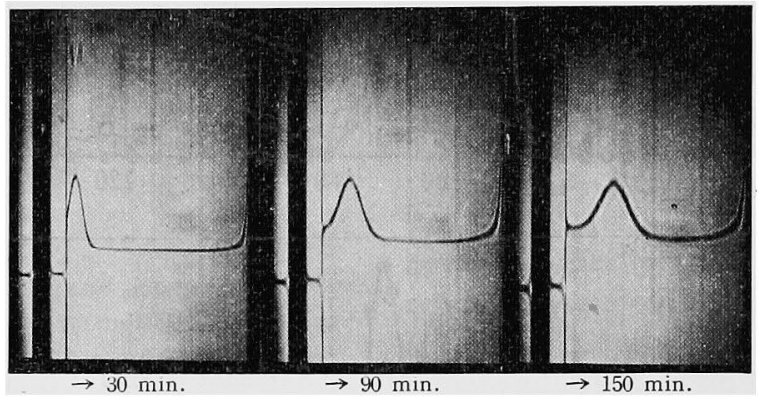

FIG. 2. Sedimentation Patterns of Alkaline Proteinase from Aspergillus sojae.

One decimal two per cent enzyme protein solution in phosphate buffer containing $\mathrm{NaCl}(\mu=0.1)$. Temperature was $10^{\circ} \mathrm{C}$. The photographs were taken at indicated time reachings after full speed (55, 430 r.p.m.).

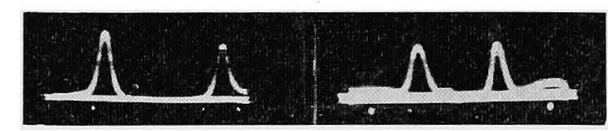

$60 \mathrm{min.} \mathrm{O} \rightarrow$

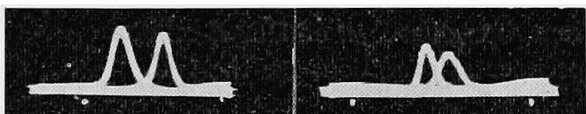

$160 \mathrm{~min}$.
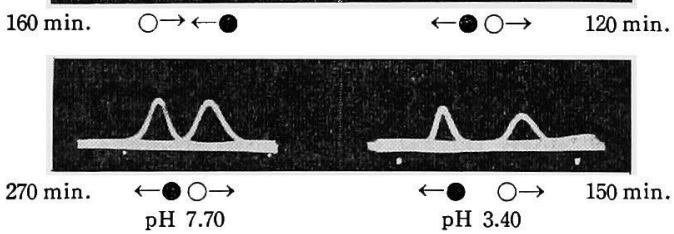

FIG. 3. Moving-boundary Electrophoretic Patterns of Alkaline Proteinase from Aspergillus sojae at $\mathrm{pHI} 7.7$ and $\mathrm{pH} 3.4$.

Left: $1.6 \%$ of enzyme protein in Veronal buffer ( $\mathrm{pH} 7.7, \mu=0.1$ ); Right: $1.4 \%$ of enzyme protein in glycine- $\mathrm{HCl}$ buffer $(\mathrm{pH} 3.4, \mu=0.1) .6 \mathrm{~mA}$, $0^{\circ} \mathrm{C}$.

Arrows show the direction of movement of boundary.

descending; $\leftarrow$; $\quad$ ascending $\bigcirc \rightarrow$
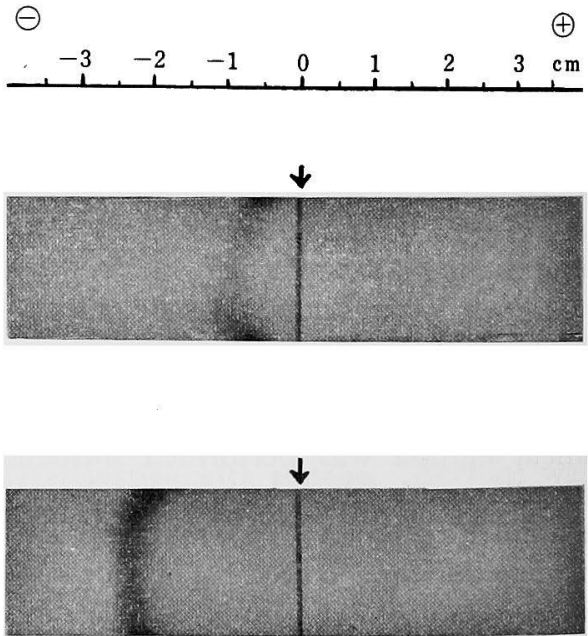

FIG. 4. Paper-electrophoretic Patterns of Alkaline Proteinase from Aspergillus sojae.

Electrophoresis was carried out on Toyo filter paper No. 51 , at $500 \mathrm{~V}$, for $16 \mathrm{hr} ., 4^{\circ} \mathrm{C}$. Applied enzyme was $200 \mu \mathrm{g}$.

Upper: Acetate buffer containing $\mathrm{NaCl}(\mathrm{pH} 4.0$, $\mu=0.05)$; Lower: Veronal-HCl buffer containing $\mathrm{NaCl}$ ( $\mathrm{pH} 7.8, \mu=0.05$ ).

Arrows show the line of application. 
of Mizunuma et al. ${ }^{2)}$ Six kilograms of the wheat bran culture of Aspergillus sojae strain $\mathrm{X} 816$ yields about $1.2 \mathrm{~g}$ of the purified enzyme, amounting to about $12 \%$ recovery of total proteolytic activity.

\section{2) Homogenety Studies}

The purity of the final enzyme preparation, which seemed to be pure by criteria, such as chromatographical behavior, the absence of accompanying other enzyme activities, and a constant specific activity throughout the proteinase peak, was further comfirmed by the following tests. Ultracentrifugal and movingboundary electrophoretical analyses showed that the preparation was monodispersive. (Fig. 2 and 3) For the paper electrophoresis a large amount of the enzyme $(200 \mu \mathrm{g})$ was applied, but even a minor impurity could not be detected. (Fig. 4)

\section{3) Some Evidence as Simple Protein}

Subramanian et al. reported the presence of some carbohydrate ( $1 \sim 2 \%$, equibalent of mannose) in their purified alkaline proteinase from Aspergillus oryzae. As shown in Table II, it was concluded that the purified enzyme from

Tablb II. Analysis of Carbohydrates AND Phosphorus IN ALKaline ProteINASE FROM Aspergillus sojae

Method

Carbohydrates

Phenol- $\mathrm{H}_{2} \mathrm{SO}_{4}{ }^{16)} \quad 0.04$ as $d$-glucose

Orcin- $\mathrm{H}_{2} \mathrm{SO}_{4}{ }^{1 \mathrm{i})} \quad 0.06$ as $d$-glucose

Orcin-HCl-FeCl ${ }_{3}{ }^{18}$ ) $\quad 0.03$ as $d$-xylose

Elson-Morgan' ${ }^{19}$ ) $\quad 0.05$ as $d$-glucosamine- $\mathrm{HCl}$

Naphthoresorcinol ${ }^{20}$ ) 0.00 as $d$-glucuronic acid

Phosphorus

Allen-Nakamura's ${ }^{21)} \quad 0.014$ as $\mathrm{KH}_{2} \mathrm{PO}_{4}$

* Calculated assuming the molecular weight of this enzyme to be $25,500 . .^{13}$ )

Aspergillus sojae did not contain any carbohydrate and phosphorus, suggesting that this enzyme is a simple protein.

Acknow ledgement. The authors wish to express their thanks to Dr. E. Ichishima, Mr. I. Koshiyama and Mr. K. Uchida of this institute for their valuable suggestion. The authors also wish to thank Dr. T. Yokotsuka and Dr. F. Yoshida for their support and encouragement. 